\title{
Portrayal of Gender Egalitarianism as an Elusive Dream for Women: A Study of Vijay Tendulkar's Silence! The Court is in Session
}

\author{
T. Sri Devi \\ Department of English and Other Foreign Languages, SRM Institute \\ of Science and Technology, Ramapuram, Chennai, India
}

\section{ABSTRACT}

Vijay Tendulkar who is nicknamed as India's angry young man has engraved his indelible name as one of the greatest dramatists in Indian Writing in English because it is he who has changed the face of Indian society. His One-act Plays are his effective tools of informative entertainment. Silence! The Court is in Session that has been translated by Priya Adarkar into English after Tendulkar has written it in Marathi as Shantata! Court Chalu Ahe in 1963 and staged in the year 1967. It has been about the victimization of an individual woman by the patriarchal society as well as by hegemonic power structures. This paper discusses and analyses gender disparity and inequality, and the need for gender egalitarianism with special focus on Leela Benare, the protagonist of the play. Leela Benare defies being the silenced by men and a woman of her dramatic group. She has a mind of her own, enjoys her own restricted life, and defies male hegemony and societal constraints. As an empowered woman, she is economically free and she need not depend on any one for her livelihood. Yet, her life is made pathetic by the patriarchal goons like her maternal uncle, Professor Damle and other men with whom she is not only a friend but also one of the artists in their dramatic troupe. Adding fuel to the fire, another woman in the troupe Mrs Kashikar also fails to support her as a result of which social justice is a distant dream for Leela Benare. The two women are two distinct personalities with minds of their own. The former never speaks of her mind in support of another woman in Leela Benare whereas the latter never seeks societal acceptance, and she is always silenced by her patriarchal dramatic troupe. Tendulkar through the play has shown how woman are silenced by patriarchy and systemic oppression, since power hierarchies are only within the purview of men. Gender egalitarianism is an elusive dream not only for Leela Benare but also for Mrs. Kashikar, as they are caught up and silenced in the rigmarole of the patriarchal world. Tendulkar through the play has asked for a change in the mentality of hypocritical Indian men and patriarchal Indian society, seeking egalitarianism for Indian women because egalitarianism continues to be an elusive dream for them.

KEY WORDS: GENDER, EGALITARIANISM, PATRIARCHY, HEGEMONIC STRUCTURE, OPPRESSION.

\section{INTRODUCTION}

Analysis: Women down the ages have been forced to play only the secondary roles to their men in the patriarchal societies and their needs have continued to remain unheard and unfulfilled. Indian society is no exception in this regard. It is the one, which is deeply

Biosc Biotech Res Comm P-ISSN: 0974-6455 E-ISSN: 2321-4007

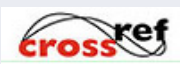

Identifiers and Pagination

Year: 2021 Vol: 14 No (8) Special Issue

Pages: 184-187

This is an open access article under Creative

Commons License Attribn 4.0 Intl (CC-BY). DOI: $h t t p: / / d x$.doi.org/10.21786/bbrc/14.8.42 steeped in patriarchal diktats and culture that gives an upper hand only to men and women are made to play only secondary but silent roles. However, conflicts of interests between men and women cannot be avoided in human relationship. It is because "values and structures continue to be patriarchal and the tradition continues to define roles and respectability, especially in a traditional society like ours" (Jain 91).

Indian men being hypocrite cannot but oppress Indian women and so both hypocrisy and oppression are the inherent traits of every man. Indian men and society expect every Indian woman to be chaste, benevolent, virtuous, patient, self-denying, enduring, self-sacrificing, and self-effacing. Both remain unchanged in this attitude. But times are changing and women like men become
Article Information

Received: 09 $9^{\text {th }}$ June 2021 ccepted after revision: $20^{\text {th }}$ July 2021 
empowered and independent in the twenty first century. But only the time will tell how far this modern Indian woman will be successful in their attempts. However, "[the] success mainly depends upon their strong will power and the way [they] accomplish it" (Dhavelswarapu 8). Moreover, the domination of patriarchy cannot be easily done away with since deciding authority what women should do lies only in the hands of men and patriarchal society. This paper discusses and analyses gender disparity and inequality and the need for gender egalitarianism with special focus on Leela Benare, the protagonist of the play Silence! The Court Is in Session.

Selt-Assertive Leela Benare: The woman protagonist of the play Leela Benare defies all attempts, forcing her to be a silenced one. She has a mind of her own and so she enjoys her own restricted life and defies male hegemony and societal constrictions. As an educated woman who is economically free, she has little to sob over. Yet, her life is made a sob sod by patriarchal goons like her maternal uncle and Professor Damle and other men, with whom she is friendly with. Tendulkar has been cautious in showing the fact that women educated or uneducated, economically dependent or independents are forced to face the rampage of patriarchal goons when they are psychologically manipulated to accept male hegemony and bow down to it. The play portrays the conformity women are forced to undergo in one name or the other. Benare has also been a victim of sexual abuse, despite being a well-educated, intelligent woman.

Generally, Tendulkar's women characters "undergo a series of sufferings and tortures as the victims of the hegemonic power -structure. In silence! the focal point, the interest lies in the struggle between women like Benare and her antagonists headed by the orthodox Kashikar and his associates" (Paul 34). Leela Benare has seen the ups and downs in her life. She has a say of her own. She talks pleasant and becomes friendly with her colleagues and management. She never likes those people who act against her desires. Her words to Samant "Who are these people to say what I can or can't do? My will is my own. I haven't sold it to anyone for a job!. My will is my own. My wishes are my own. No one can kill those- no one! I'll do what I like with myself and my life! I'll decide" (Act I 6-7) reveals this trait. But her way of behaviour as a scapegoat in the midst of dominating men like Kashikars, Samant, Ponshke, Sukhatme and Rokde makes one unbelievably believable. She looks like a dissected mime in an atrocious mock trial that gurgles her life in and out.

Prepollent Patriarchal System: Leela Benare is in her midthirties, and she is unmarried. She earns her livelihood as a teacher and leads a life without any financial difficulty. She is the breadwinner of her home supporting her maternal home members. She is an intense woman, who has been duped by society and her own people alike. She can be compared to Sarita of Kamala, Laxmi of Shakaram Binder, Jyoti of Kanyadan by Tendulkar, and Alika of Bravely Fought the Queen by Mahesh Dattani. She is disliked for being a woman with a verse to go against the grain. She goes against societal norms and becomes an unwed mother. Her sexual morality is questioned by the Kashikars, Samant, Ponshke, Sukhatme, Rokde and others as she has taken a mighty flight as an unwed mother, and she does not reveal the name of the father of the child easily. Prof. Damle, the man responsible for the child, is absent throughout the mock trial. Little do the other characters realize that they have made a scapegoat of a good woman who has been cheated by a man like Professor Damle.

In a patriarchal society, an unmarried woman in her thirties is seen as a threat to society. That too an unmarried woman with a mind of her own is seen as an abettor of society who spoils it and spreads wrong values and violates the moral code of conduct. The Kashikars, Samant, pancake, Sukhatme, Rokde and others during the mock trial question Leela about her very being, her promiscuity her unwedded motherhood, and accuse her of infanticide. Leela Benare is an educated woman with a liberated mind, yet she is the victim of a covert love with sexual attack at a young age in her teens, and yet another covert, love cum sexual assault in her mid-thirties. Patriarchy is the manifestation and institutionalization of male dominance over women in society in general. It implies that men hold power in all the important institutions of society and that women are deprived of access to such power (Learner 239).

The Beguilement: The way Leela is psychologically manipulated to accept the dictates of a patriarchal tool like Damle depicts the plight of modern Indian women, who are controlled by their physical, sexual self, and then their mind. Moreover, patriarchy does not allow any woman to have any other identity other than the one as a daughter and a wife. Moreover, Freud has clearly pointed out the fact that "a woman's sexuality is evolved as fully as man's" (qtd.in Beauvoir 66). Despite scientific evidence regarding the aforesaid fact, the sexuality as well as sexual expression of women is undermined, and it is never given its due. Men who get involved in such sexual activities with women are praised as studs, whereas women who enjoy the same are sidelined as duds. They are also treated as the disposal ones after having been sexually exploited as seen in the case of Leela Benare. Subha Tiwari in her article titled "Silence! The Court is Session - A Strong Social Commentary" has adroitly pointed out the differences in the treatment of men and women as far as their sexual morality is concerned:

The whole responsibility of morally upright behaviour is bulldozed on women. Men are by nature considered to be willful, wild, childish, innocent, and mischievous. Their sins are no sins at all. The society has a very light parental and pampering sort of attitude when it comes to sexual offences of men. In the case of women, the iron rod gets hotter and hotter. No punishment is actually enough for such a woman. There is no respite no hade and soothing cushion for such a sinning woman. She must be stained and abandoned. Her femininity, her 
needs, her very existence must be ignored or rather destroyed. She must be cornered and brutally killed both in physical and psychological senses. This play is about the pathetic positions of women in a male-dominated Indian world. (35).

Leela Benare's life has never been a cakewalk since her teen. She has undergone physical and mental ordeals in her teen and such ordeals have tempted her to make another wrong choice as an adult. She herself reveals this when she says, "I used to cry my guts out. I used to wish my heart would break! My life was a burden to me (heaving a great sigh). But when you can't lose it, you realize the value of it. You realize the value of living. You see what happiness means" (Act III 102). However, she comes out matured after her complete realization. She has been ostracized by others for being a woman with none to support her. She admits having committed a sin and having slept with her maternal uncle, who made love to her in her prime youth. When she insisted on marriage, he left her in the lurch and walked away feeling satisfied with his sexual relationship with her: I insisted on marriage. So, I could live my beautiful, lovely dream openly. But all of the -my mother too-were against it. And my brave man turned tail and ran. Such a rage- I felt such a rage against him them- I felt like smashing his face in public and spitting on it!. I threw myself off a parapet of outhouse to embrace death. But I didn't die. (Act III 105).

Incriminating The Self: Tendulkar through the character of Benare points out how bold Benare is when she accepts her faults. She has done what she has wanted, and, in this regard, she is not a hypocrite like many women. During her young age, she has been psychologically manipulated by an older man for his physical intimacy. Benare accepts the legality of marriage because she knows, "Marriage alone permits a woman [not only] to keep her social dignity intact [but also] to find fulfillment as loved one [as a wife and mother]" (Beauvoir 71-72). Marriage has been denied to her even by her mother. She develops bravery when life becomes a burden, because of her maternal uncle. She studies and becomes a teacher, earns money, and becomes independent. Moreover, she does social work, and she is also a part of an amateur theatre group, so that she can be very busy.

Never do all women have the same sort of needs, desires, and requirements. There is a variation in the needs and necessities of a lower class, middle class, and upperclass women. There is a difference between the vistas of an educated woman and an uneducated woman, an economically dependent woman and an economically independent woman. Women's needs vary from country to country, and race to race according to the culture prevalent there because "Culture [only] constructs differences in gender" (Morris 163). Cultural habits meant for women and female children vary in umpteen numbers of ways. Though men and women are societal beings, "gender and sex have an inherent relationship" (Morris 163). "One is not born, but rather becomes a woman"
(Beauvoir 295). Tendulkar through the novel and the protagonist's struggle puts forth the idea that there is a need to develop the consciousness of women regarding their place in society because this consciousness not only influences their lives and that of their children but also their roles as societal beings.

The other woman character who attracts the attention in the play is Mr.Kashikar, and she is always identified as Mrs. Kashikar and not by her first name. As a dutiful wife, she follows Mr.Kashikar and his verdicts in almost everything. She beautifies her hair with the flowers brought by him and follows him as and when he goes for his social work and drama rehearsals. As a financially dependent woman, she clamours for the attention of her husband, and she always does the best only to please him. Leela Benare, as a modern woman, is very much different from her traditional counterpart Mrs. Kashikar and she is a complete foil to her. Tendulkar showcases the hypocrisy of Indian society and the triviality of human nature through the play. Mrs. Kashikar is always looked down upon for being childless, whereas Miss Benare becomes an unwed mother and as such she is treated like a cancerous canker of Indian society. Neither Mrs. Kashikar nor Miss Leela Benare is given her respective due for who they are. Neither is their frankness nor is their humane personality given grace.

Mrs.Kashikar is given respect after she bows down to patriarchal diktats and standards, unlike Leela Benare. Moreover, she becomes a patriarchal tool putting forth gruesome questions during the mock trial, which after all is conducted to know about Leela Benare's life. They both share a hypocritical relationship as women acquaintances. After the spiteful mock trail, there can be no friendship between them. Mrs.Kashikar might seem to be the worthless trophy wife of Mr.Kashikar but she makes her way out in a patriarchal society. Despite all of Leela Benare's independence, education, financial stability, beauty, truth and straightforwardness, it is Mrs. Kahiskar who has societal acceptance, as she bows down to patriarchal diktats of Indian womanhood being the unquestioning housewife.

Benare has some eight years of experience as a teacher. She overcomes much vulnerability, becomes busy with life, does a social work, gets involved in theatre and develops a passion for life. Damle a professor with gusto gets hold of Benare with gusto, makes her fall for him and his love, makes her pregnant and leaves her in the lurch. The educated man in the disguise of a cunning Woolf uses the gullibility of Leela, gives her pipe dreams and leaves her to her fate forever. Leela gathers all her strength only to know that she has been cheated beyond recognition. She realizes that she has fallen in love with the wrong man for the second time, and she has been made a mausoleum of disgrace with charges of infanticide levied on her as a mother and a person. The happiness of being a mother percolates into a disgraceful and unwanted event and with an unwed motherhood, she is a bane in India. Benare after all the 
struggles in her life falls in love and becomes a mother, and she is denied the very right by society as the legal second wife of Damle.

\section{CONCLUSION}

Social justice is a distant dream for Mrs. Kashikar and Leela Benare. The two women are two distinct personalities with minds of their own. The former never speaks her mind to be accepted on all fronts and the latter never minds about societal acceptance and she is made silent by patriarchal goons and tools in due course of time. Tendulkar through the play has shown how women are silenced by patriarch and systemic oppression as power hierarchies are within the purview of men. Gender egalitarianism is an elusive dream for both the women as they are caught up in the rigmarole of a patriarchal world that offers patriarchal diktats and nothing else. The play shows how Indian women like Mrs.Kashiakr, Leela Benare and possibly other women who constitute half the population in India are silenced as the other citizens in a secular, democratic nation. Indian women's second-class citizen status is made evident through the play. Tendulkar through the play has asked for a change in the mentality of hypocritical Indian men, and Indian society seeking egalitarianism for women, as it is an elusive dream for them, that can change their life forever.

\section{REFERENCES}

Beauvoir, Simone de.( 1972) The Second Sex.1949. Translated by H.M. Parshley, Penguin, pp. 609, 486.
Contemporary Indian Dramatists. Atlantic Publishers. 2007. Print.

Dharan. N.S.( 1999) "Gynocriticism in Silence! The Court is in Session and Kamala The Plays of Vijay Tendulkar. New Delhi: Creative Books. Print.

Dhavaleswarapu, Ratna Hasanthi.( 2014) “Conflicting Interests of Women Characters: A Study of Anita Desai's Early Novels". Sai Om Journal of Arts and Education. India: Sai Om Publications. Volume 1 issue 4 May. Print.

Jain. Jasbir.( 2001) "Positioning the Post in PostFeminism: Reworking of Strategies?” Ed. Jasbir Jain. Avadesh Kumar Singh. Indian Feminism, New Delhi: Creative Books. Print.

Morris, E. Jerome, Encyclopedia of Race Ethnicity and Society. Ed. Sahaefer T. Richard.

Paul Smita. (2010) Theatre of Power, Kolkata: Books way Publishers \&t Distributors, Print.

Tendulkar, Vijay. (1992) “A Testament”. Indian Literature No. 147. Jan-Feb. Print.

Tendulkar, Vijay. (1993) Interview Elizabeth Roy. Indian Review of Books Vol 2. No.7 Apr-May.. Print.

Tendulkar, Vijay. (2017) Silence! The Court is in Session, New Delhi: Oxford University Press.. Print.

Tiwari, Shubha. "Silence! The Court is in Session -A strong Social commentary” Ed.

Volume 1 United Kingdom: Sage Publications 2008. Print. 